Article

\title{
Soil Organic Matter Degradation in Long-Term Maize Cultivation and Insufficient Organic Fertilization
}

\author{
Jiří Balík*, Martin Kulhánek ${ }^{\circledR}$, Jindřich Černý, Ondřej Sedlář and Pavel Suran
}

Department of Agro-Environmental Chemistry and Plant Nutrition, Faculty of Agrobiology, Food and Natural Resources, Czech University of Life Sciences, 16500 Prague, Czech Republic; kulhanek@af.czu.cz (M.K.); cernyj@af.czu.cz (J.Č.); sedlar@af.czu.cz (O.S.); suranp@af.czu.cz (P.S.)

* Correspondence: balik@af.czu.cz

Received: 1 August 2020; Accepted: 11 September 2020; Published: 17 September 2020

\begin{abstract}
Soil organic matter carbon ( $\mathrm{C}_{\mathrm{SOM}}$ ) compounds degradation was observed in long-term field experiments with silage maize monoculture. Over a period of 26 years, the content of carbon in topsoil decreased by $22 \%$ in control unfertilized plots compared to $25 \%$ and $26 \%$ in treatments fertilized annually with mineral nitrogen. With annual wheat straw application (together with mineral $\mathrm{N}$ ), the content of $\mathrm{C}_{\mathrm{SOM}}$ decreased by $8 \%$. Contrary to that, the annual application of farmyard manure resulted in a $\mathrm{C}_{\mathrm{SOM}}$ increase of $16 \%$. The ratio of carbon produced by maize related to total topsoil $\mathrm{C}_{\mathrm{SOM}}$ content ranged between $8.1-11.8 \%$. In plots with mineral $\mathrm{N}$ fertilization, this ratio was always higher than in the unfertilized control plots. With the weaker soil extraction agent $\left(\mathrm{CaCl}_{2}\right)$, the ratio of carbon produced by maize was determined to be $17.9-20.7 \%$. With stronger extraction agent (pyrophosphate) it was only $10.2-14.6 \%$. This shows that maize produced mostly unstable carbon compounds. Mineral N application resulted in stronger mineralization of original and stable organic matter compared to the unfertilized control. However, the increase of maize-produced carbon content in fertilized plots did not compensate for the decrease of "old" organic matter. As a result, a tendency to decrease total $\mathrm{C}_{\mathrm{SOM}}$ content in plots with mineral $\mathrm{N}$ applied was observed.
\end{abstract}

Keywords: C balance; humic acids; fulvic acids; mineral N; farmyard manure; straw

\section{Introduction}

The amount and quality of soil organic matter $\left(\mathrm{C}_{\mathrm{SOM}}\right)$ are very significant parameters for assessing soil fertility. $\mathrm{C}_{\mathrm{SOM}}$ is influenced by a range of soil-climatic conditions, systems of soil management, cultivated crops, fertilization, agrotechnical issues, etc. Agricultural crops differ significantly in the amount and quality of post-harvest residues and root biomass. The crops with high potential to decrease the content of organic matter in soil comprise maize, especially if grown for silage [1]. Loges et al. [2] compared the average amount of post-harvest residues and roots among maize monoculture and rotated crops (clover grass-maize-wheat). The amount of carbon supplied into the soil (post-harvest residues + roots) was $1.3 \mathrm{t} \mathrm{ha}^{-1}$ year $^{-1}$ in the case of monoculture, compared to $1.6 \mathrm{t} \mathrm{ha}^{-1}$ year $^{-1}$ in crop rotation. As a result of mineralization, the annual carbon decrease was $530 \mathrm{~kg} \mathrm{C} \mathrm{ha}^{-1}$ year $^{-1}$ in monoculture, whereas in crop rotation it was only $120 \mathrm{~kg} \mathrm{C} \mathrm{ha}^{-1}$ year $^{-1}$.

$\mathrm{C}_{\mathrm{SOM}}$ can be divided into stable and labile fractions. Stable carbon forms are represented by humic acids $\left(\mathrm{C}_{\mathrm{HA}}\right)$, fulvic acids $\left(\mathrm{C}_{\mathrm{FA}}\right)$, and humins $\left(\mathrm{C}_{\mathrm{HU}}\right)$. Carbon sequestration in terms of $\mathrm{C}_{\mathrm{HA}}, \mathrm{C}_{\mathrm{FA}}$, and $\mathrm{C}_{\mathrm{HU}}$ content and quality is very important to understand soil quality degradation $[3,4]$.

Gregorich et al. [5] found that after seven years of maize cultivation as a monoculture, the ratio of carbon originating from maize $\left(\mathrm{C}_{4}\right)$ related to $\mathrm{C}_{\mathrm{SOM}}\left(\mathrm{C}_{4} / \mathrm{C}_{\mathrm{SOM}}\right)$ was only $15 \%$ of total $\mathrm{C}_{\mathrm{SOM}}$. The previous crop was permanent grass stand. Collins et al. [6] determined the $C_{4}$ ratio in $C_{S O M}$ as $23-60 \%$ in fertilized plots and $9-32 \%$ in unfertilized control plots. These results were obtained in the main 
maize-growing regions in the USA in fields with maize cultivated for $8-35$ years. Similarly, $[7,8]$ reported higher $\mathrm{C}_{4}$ ratios in fertilized plots compared to unfertilized ones; this was affected mainly by higher biomass yields (including root biomass) in the fertilized crop. Bettina et al. [9] evaluated experiments lasting 40 years with maize monoculture, which followed after rye monoculture. The $\mathrm{C}_{4}$ ratio in $\mathrm{C}_{\mathrm{SOM}}$ was $9.5 \%$ and $14.1 \%$ in unfertilized crops and fertilized crops in topsoil, respectively; the values for subsoil were $5.7 \%$ (no fertilization) and 7.2\% (fertilization). Bettina et al. [9] presumed that the main reason for the lower $C_{4}$ ratio compared to other studies was the growing of maize for silage in their experiments. Almost all the biomass was thus harvested and removed from the fields and only low stubble remained. Similarly, low $\mathrm{C}_{4}$ ratios were also reported by $[10,11]$.

Maize biomass carbon is easily mineralized in the soil; hence, the increased $C_{4}$ ratio is determined mostly in easily hydrolysable fractions $\left(\mathrm{C}_{\mathrm{DOC}}\right)$. Depending on the purpose of cultivation (silage/grain), length of monoculture cultivation, a system of fertilization, soil-climatic conditions, the $\mathrm{C}_{4}$ ratio in $C_{\text {DOC }}$ was almost $1 / 3[5,9,12]$. Fertilized plots also had higher total content of $C_{D O C}$ [13]. Even higher values than in $C_{D O C}$ were observed for $C_{4}$ in microbial biomass carbon $\left.[5,9]\right)$, again with the values of fertilized plots being higher. The results also show that "younger" organic matter (plant residues) is mineralized more quickly than "older" organic matter in the soil. $\mathrm{C}_{4}$ thus accounts for the main share of carbon loss in the form of $\mathrm{CO}_{2}$; Bettina et al. [9] reported almost $80.0 \%$.

The trials of Loges et al. [2] suggest the ratio of root biomass and exudates as $18 \%$ compared to the aboveground biomass. Out of the $\mathrm{C}$ amount in roots and post-harvest residues, the main part remains in the topsoil and a lesser amount in subsoil [9,14-16]. Loges et al. [2] presumed that it was sufficient to examine the $0-30 \mathrm{~cm}$ soil layer to determine the impacts of different cultivation systems on post-harvest residues' $C$ input into soil. Rasse et al. [10] found almost all $C_{4}$ in the depth $0-90 \mathrm{~cm}$, $63 \%$ of it being in the $0-30 \mathrm{~cm}$ layer. In the subsoil, the content of $\mathrm{C}_{\mathrm{SOM}}$ is significantly lower and more stable [17]. The reason is a tighter relationship of organic matter to clay particles [18] and also a lower air content, i.e., lower mineralization intensity.

The aim of this paper was to assess the changes in $\mathrm{C}_{\mathrm{SOM}}$ amount and quality in long-term silage maize monoculture, as well as compare the effects of different mineral and organic fertilizers. This research is also important from the viewpoint of long-term sustainable soil management in the Czech Republic (CR), with respect to increasing usage of maize in biogas plants [19], low intensity of organic fertilization of maize and other crops, and unbalanced $C$ in agricultural systems. These issues are very important, as shown by the high ratio of maize in crop rotations. Moreover, maize is often grown for several consecutive years without rotation. In the CR, its acreage is $10.5 \%$ of agricultural soils—about 232,400 ha being silage maize $+74,800$ ha for grain [20]. Furthermore, luvisol (the soil type chosen for our experiment) is representing $4.29 \%$ of the area of agriculturally used soils in the CR, which means 179,167 ha [21].

\section{Results}

The explanation of abbreviations is mentioned above in the list of abbreviations and further in the chapter materials and methods.

\subsection{Yield Parameters}

Differences in yields of harvested biomass over a period of 26 years are shown in Figure 1. Although the differences among fertilized treatments are relatively high (sometime even 18\%), statistically significant differences were not observed. This is mainly due to the variability of climatic conditions during experimental seasons, where the effect of individual fertilization varied according to related season. 


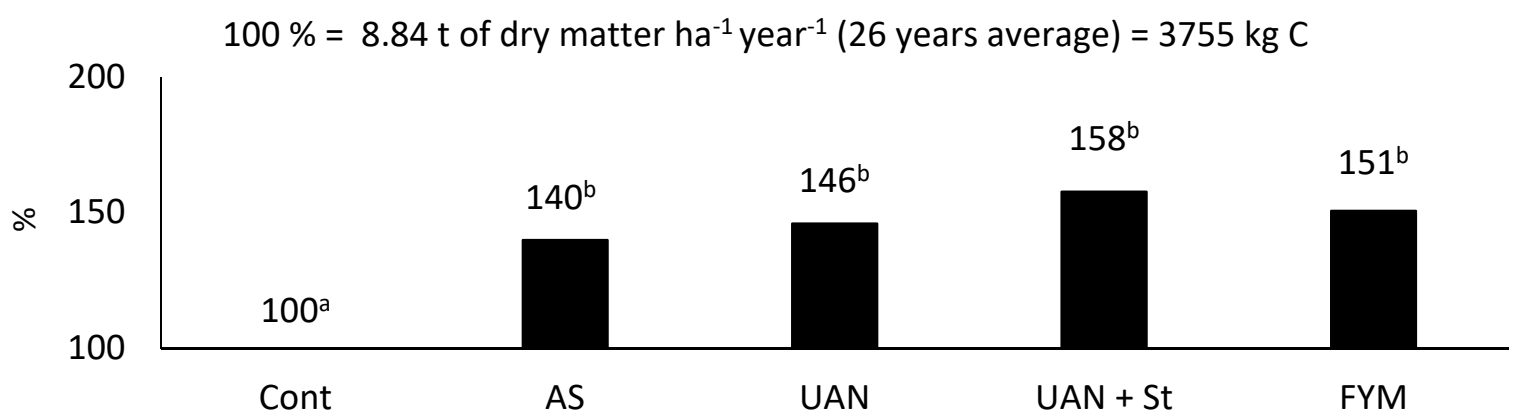

Figure 1. Average maize biomass yield; different letters behind the values are meaning significant differences among investigated treatments (Tukey test; $p<0.05$ ); number of replications per treatment $n=4$.

The values in fertilized plots reached 12.2-14.0 t DM ha ${ }^{-1}$ and correspond to site conditions. The highest yields were obtained in the urea ammonium nitrate (UAN) + straw (St) treatment (Figure 1) with the highest $\mathrm{N}$ dose applied, i.e., $153.5 \mathrm{~kg} \mathrm{~N} \mathrm{ha}^{-1}$ year $^{-1}(120+33.5)$ (see the chapter methodology).

\subsection{Carbon Produced by Maize}

Table 1 summarizes the maize carbon $\left(C_{4}\right)$ results. The obtained average yields of dry matter and its $\mathrm{C}$ content were used to calculate the amount of carbon transported every year from the field. The yield of $8.84 \mathrm{t} \mathrm{DM} \mathrm{ha}^{-1}$ also represents $3755 \mathrm{~kg} \mathrm{C} \mathrm{ha}^{-1}$. The amount of carbon in post-harvest residues (stubble) was determined experimentally in 2018. The total carbon accumulated in the aboveground biomass was calculated as the sum of "harvest" + "stubble" values. Similarly, the carbon amount in topsoil roots was obtained by analyses in 2018 (at the harvest period). To compare our experimentally determined results, the values calculated based on various algorithms reported in the literature are presented in Table 1.

Table 1. Carbon balance of maize $\left(\mathrm{kg} \mathrm{C}\right.$ ha year $\left.{ }^{-1}\right)$; AS-ammonium sulfate, UAN-urea ammonium nitrate, UAN + st-urea ammonium nitrate + straw, FYM-farmyard manure.

\begin{tabular}{cccccc}
\hline \multirow{2}{*}{ Treatment } & \multicolumn{3}{c}{ Above Ground Biomass } & Roots + Exudates $^{\mathbf{3}}$ \\
\cline { 2 - 6 } & $\begin{array}{c}\text { Transport by } \\
\text { Harvest }{ }^{\mathbf{1}} \text { Stubble }{ }^{2}\end{array}$ & $\sum$ & Roots $^{\mathbf{~}^{2}}$ & $\begin{array}{c}\text { Loges et al. [2] } \\
\text { Rasse et al. [10] }\end{array}$ \\
\hline Control & 3755 & 208 & 3963 & 394 & 548 \\
AS & 5210 & 255 & 5466 & 736 & 756 \\
UAN & 5421 & 322 & 5743 & 696 & 794 \\
UAN + St & 5854 & 293 & 6147 & 809 & 850 \\
FYM & 5615 & 360 & 5975 & 768 & 826
\end{tabular}

${ }^{1}$ Average value of 26 year period; ${ }^{2}$ Determined in the year $2018 ;{ }^{3}$ Calculated according to Rasse et al. [10] and Loges et al. [2].

\subsection{The Changes of Soil Organic Matter Carbon $\left(C_{S O M}\right)$ Contents}

In 1993, the amount of $C_{\mathrm{SOM}}$ in the topsoil was $1.26 \%$. After harvest in 2018, the following values were determined: control $0.98 \%$, ammonium sulfate (AS) $0.93 \%$, UAN $0.95 \%$, UAN + St $1.16 \%$, manure $1.49 \%$ (Figure 2). There was a significant decrease of $\mathrm{C}_{\mathrm{SOM}}$ in the topsoil of all treatments, except for farmyard manure. In relative values, the $\mathrm{C}_{\mathrm{SOM}}$ content decreased by $22 \%$ in the control and

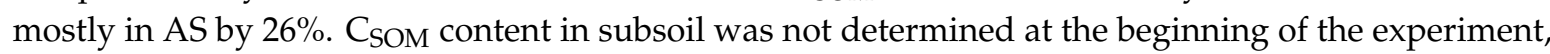
but Figure 2 clearly shows a lower $\mathrm{C}_{\mathrm{SOM}}$ content in the subsoil in the AS treatment compared to other treatments. On the contrary, treatment with farmyard manure resulted in significantly higher $\mathrm{C}_{\mathrm{SOM}}$ content also in the subsoil, which is probably related to rather deep tillage $(28 \mathrm{~cm})$. 


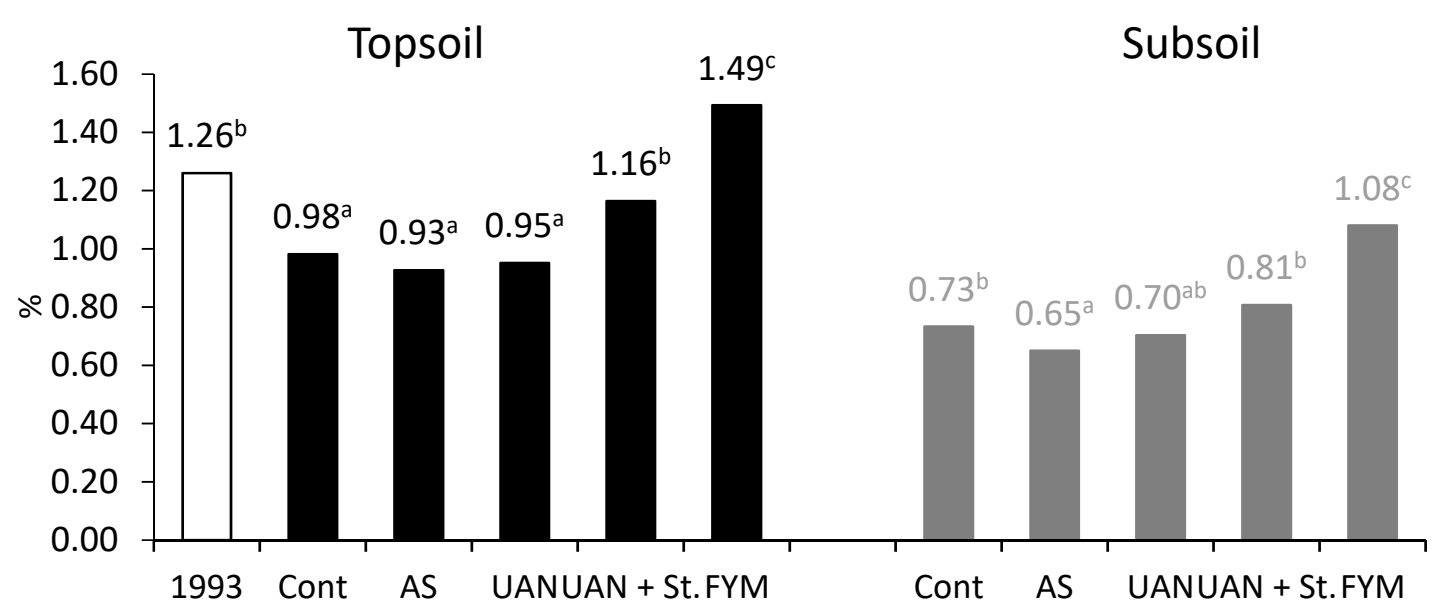

Figure 2. Soil organic matter carbon $\left(\mathrm{C}_{\mathrm{SOM}}\right)$ content in topsoil and subsoil; different letters behind the values are meaning significant differences among investigated treatments (Tukey test; $p<0.05$ ); number of replications per treatment $n=4$.

\subsection{Carbon Balance}

Table 2 presents the score of carbon losses as a result of mineralization as well as respiration of $\mathrm{CO}_{2}$. Column 2 shows the calculated difference of $\mathrm{C}_{\mathrm{SOM}}$ content at the beginning of the experiment (1993) and after harvest in 2018. For example, the loss in the AS treatment was- $571 \mathrm{~kg} \mathrm{C} \mathrm{ha}^{-1}$ year $^{-1}$. Further, the $\mathrm{C}$ amount supplied with organic fertilization was calculated, e.g., for UAN + St treatment it was $2140 \mathrm{~kg} \mathrm{C} \mathrm{ha}^{-1}$ year $^{-1}$.

Table 2. $\mathrm{C}_{\mathrm{SOM}}$ loses due to the mineralization (soil organic matter + fertilizer + crop residues) (in $\mathrm{kg}$ $\mathrm{C} \mathrm{ha}^{-1}$ year $^{-1}$ ); AS-ammonium sulfate, UAN-urea ammonium nitrate, UAN + st-urea ammonium nitrate + straw, FYM-farmyard manure, C-Carbon.

\begin{tabular}{|c|c|c|c|c|c|c|c|}
\hline Treatment & C in Topsoil ${ }^{1}$ & $\begin{array}{l}C \text { from Org. } \\
\text { Fertilizer }\end{array}$ & $\begin{array}{l}\text { C in Topsoil + C } \\
\text { from Org. Fert. }\end{array}$ & C in Stubble ${ }^{2}$ & C in Roots ${ }^{2}$ & Total C & Loses/Harvest (\%) ${ }^{3}$ \\
\hline Control & -485 & 0 & 485 & 208 & 394 & 1087 & 28.9 \\
\hline AS & -571 & 0 & 571 & 255 & 736 & 1562 & 29.7 \\
\hline $\mathrm{UAN}+\mathrm{St}$ & -173 & 2140 & 2313 & 293 & 809 & 3415 & 57.6 \\
\hline FYM & 398 & 1603 & 1205 & 360 & 768 & 2333 & 41.1 \\
\hline
\end{tabular}

The data concerning the carbon amount ploughed into the soil in the form of post-harvest residues (stubble) and roots (topsoil only) originate from our analyses in 2018. It was evident that the highest carbon losses are in the treatment UAN + St, i.e., $3415 \mathrm{~kg} \mathrm{C} \mathrm{ha}^{-1}$ year ${ }^{-1}$. These results confirm the dynamics of straw mineralization in soil. The losses in the treatment with farmyard manure were $2333 \mathrm{~kg} \mathrm{C} \mathrm{ha}^{-1}$ year $^{-1}$. Manure contains organic matter, which is significantly more stable compared to straw and affects $\mathrm{C}_{\mathrm{SOM}}$ stability considerably. Presuming that stubble residues do not significantly affect $\mathrm{C}$ content in soil and are mineralized quickly (about three times faster than manure) and further that root biomass needs a similar time to decompose as manure, about $16 \%$ transformation of carbon from manure to stable soil compounds may be deduced. The residual amount then mineralizes or may counterbalance the losses by mineralization of the original organic matter.

Methods using stable carbon isotopes $\left({ }^{13} \mathrm{C} /{ }^{12} \mathrm{C}\right)$ allowed us to determine the ratio of maize carbon $\left(\mathrm{C}_{4}\right)$ in the total topsoil and subsoil $\mathrm{C}_{\mathrm{SOM}}$. The reported analyses were assessed only for the unfertilized control plots and for mineral $\mathrm{N}$ treatments. In the fertilized plots, the content of maize carbon in total $\mathrm{C}_{\mathrm{SOM}}$ in topsoil and subsoil increased. In the topsoil of the control plots, the $\mathrm{C}_{4}$ ratio in $\mathrm{C}_{\mathrm{SOM}}$ was $8.1 \%$, in the case of AS it was $10.3 \%$, and in UAN $11.8 \%$, respectively (calculated as $C_{4} /\left(C_{3}+C_{4}\right)$ from Table 3 . 
* $100 \%$ ). The $\mathrm{C}_{4}$ ratio in $\mathrm{C}_{\mathrm{SOM}}$ in subsoil was about $25-50 \%$ lower compared to topsoil (control $5.5 \%$, AS 7.9\%, UAN 6.0\%).

Table 3. Carbon content in topsoil and subsoil; AS-ammonium sulfate, UAN-urea ammonium nitrate, $\mathrm{C}$-carbon, $\mathrm{C}_{\mathrm{SOM}}$ - soil organic matter carbon, $\mathrm{C}_{\mathrm{CaCl} 2}$-carbon determined with $0.01 \mathrm{~mol} \mathrm{~L}^{-1}$ $\mathrm{CaCl}_{2}, \mathrm{C}_{\mathrm{PF}}$ - carbon determined with 0.1. $\mathrm{mol} \mathrm{L}^{-1} \mathrm{Na}_{4} \mathrm{P}_{2} \mathrm{O}_{7}, \mathrm{C}_{3}$ - “old" soil organic matter, $\mathrm{C}_{4}$ —carbon from maize.

\begin{tabular}{|c|c|c|c|c|c|}
\hline Treatment & Soil Depth (cm) & Origin of $\mathrm{C}$ & $\mathrm{C}_{\mathrm{SOM}}\left(\mathrm{g} \mathrm{m}^{-2}\right)$ & $\mathrm{C}_{\mathrm{CaCl} 2}\left(\mathrm{~g} \mathrm{~m}^{-2}\right)$ & $C_{P F}\left(g^{-2}\right)$ \\
\hline \multirow[t]{6}{*}{ Control } & $0-30$ & $\mathrm{C}_{3}+\mathrm{C}_{4}$ & $4322^{a}$ & $1.2^{\mathrm{a}}$ & $970^{a}$ \\
\hline & & $\mathrm{C}_{3}$ & $3973^{e}$ & $0.99 \mathrm{~d}$ & $872^{d}$ \\
\hline & & $\mathrm{C}_{4}$ & $349 \mathrm{~g}$ & $0.7^{\mathrm{g}}$ & $98^{g}$ \\
\hline & $30-60$ & $\mathrm{C}_{3}+\mathrm{C}_{4}$ & $3408^{\circ}$ & & \\
\hline & & $\mathrm{C}_{3}$ & $3221^{r}$ & & \\
\hline & & $\mathrm{C}_{4}$ & $187^{\mathrm{s}}$ & & \\
\hline \multirow[t]{6}{*}{ AS } & $0-30$ & $\mathrm{C}_{3}+\mathrm{C}_{4}$ & $4101^{a}$ & $4.65^{c}$ & $1147^{b}$ \\
\hline & & $\mathrm{C}_{3}$ & $3679^{d}$ & $3.75^{f}$ & $1005^{\mathrm{f}}$ \\
\hline & & $\mathrm{C}_{4}$ & $422^{\mathrm{h}}$ & $0.9^{\mathrm{h}}$ & $142^{\mathrm{h}}$ \\
\hline & $30-60$ & $\mathrm{C}_{3}+\mathrm{C}_{4}$ & $3023 \mathrm{p}$ & & \\
\hline & & $\mathrm{C}_{3}$ & $2785 \mathrm{q}$ & & \\
\hline & & $\mathrm{C}_{4}$ & $238^{\mathrm{s}}$ & & \\
\hline \multirow[t]{6}{*}{ UAN } & $0-30$ & $\mathrm{C}_{3}+\mathrm{C}_{4}$ & $4190^{a}$ & $2.99^{b}$ & $1058^{a, b}$ \\
\hline & & $\mathrm{C}_{3}$ & $3697^{d}$ & $2.46^{\mathrm{e}}$ & 904 e,f \\
\hline & & $\mathrm{C}_{4}$ & $493^{\mathrm{h}}$ & $0.53^{h}$ & $154^{\mathrm{h}}$ \\
\hline & $30-60$ & $\mathrm{C}_{3}+\mathrm{C}_{4}$ & $3269^{o, p}$ & & \\
\hline & & $\mathrm{C}_{3}$ & $3073 \mathrm{q}$ & & \\
\hline & & $\mathrm{C}_{4}$ & $196^{\mathrm{s}}$ & & \\
\hline
\end{tabular}

Within columns, values followed by the same letter (for topsoil: a-c for total amounts; $\mathrm{d}-\mathrm{f}$ for $\mathrm{C}_{3}$ derived carbon; $\mathrm{g}-\mathrm{h}$ for $\mathrm{C}_{4}$ derived carbon and for subsoil o- $\mathrm{p}$ total amount; $\mathrm{q}-\mathrm{r}$ for $\mathrm{C}_{3}, \mathrm{~s}-\mathrm{t}$ for $\mathrm{C}_{4}$ ), are not significantly different (Tukey test, $p<0.05$ ) between experiment plots. Number of replications $n=4$.

Table 3 shows statistically conclusive differences in the content of "old" organic matter $\left(C_{3}\right)$ among control and $\mathrm{N}$ fertilization treatments. In the case of AS and UAN treatments, stronger mineralization of original and stable $\mathrm{C}_{\mathrm{SOM}}$ occurred compared to the control. Contrariwise, $\mathrm{N}$ mineral fertilization resulted in a significant increase in $\mathrm{C}_{4}$ content. This process also occurs in the subsoil, yet it is less dynamic. The values reported in Table 3 further demonstrate that mineral $\mathrm{N}$ fertilization alone increases hydrolysis of $\mathrm{C}_{\mathrm{SOM}}$, which is manifested by a significant increase of extractable organic compounds. $\mathrm{C}_{\mathrm{CaCl} 2}$ represents the carbon determined with the weak extracting agent and $\mathrm{C}_{\mathrm{PF}}$ with strong one, respectively. It was evident that $\mathrm{C}_{4}$ comprises mostly unstable and easily hydrolysable forms. The ratio of $\mathrm{C}_{4}$ in $\mathrm{C}_{\mathrm{CaCl}}$ was $17.9-20.7 \%$; in $\mathrm{C}_{\mathrm{PF}}$ it was $10.2-14.6 \%$.

\subsection{The Soil Organic Matter Quality Parameters}

The relationship between the amount of extractable carbon and total $\mathrm{C}_{\mathrm{SOM}}$ is shown in Figure 3. The highest values were obtained in the AS treatment. The lowest ratios of $\mathrm{C}_{\mathrm{CaCl} 2}$ and $\mathrm{C}_{\mathrm{PF}}$ to $\mathrm{C}_{\mathrm{SOM}}$ were always obtained in the control and farmyard manure treatments, which suggests higher stability of organic matter in soil compared to other treatments. High values in the UAN + St treatment confirm previous results of rather fast mineralization of straw in soil (Table 2). Figure 4 shows the total amount of extractable carbon using $\mathrm{CaCl}_{2}$ or $\mathrm{Na}_{4} \mathrm{P}_{2} \mathrm{O}_{7}$. Considering the high total $\mathrm{C}_{5 \mathrm{OM}}$ content in the farmyard manure treatment, high carbon values were also obtained at the extraction with a strong solution of $\mathrm{Na}_{4} \mathrm{P}_{2} \mathrm{O}_{7}$. 

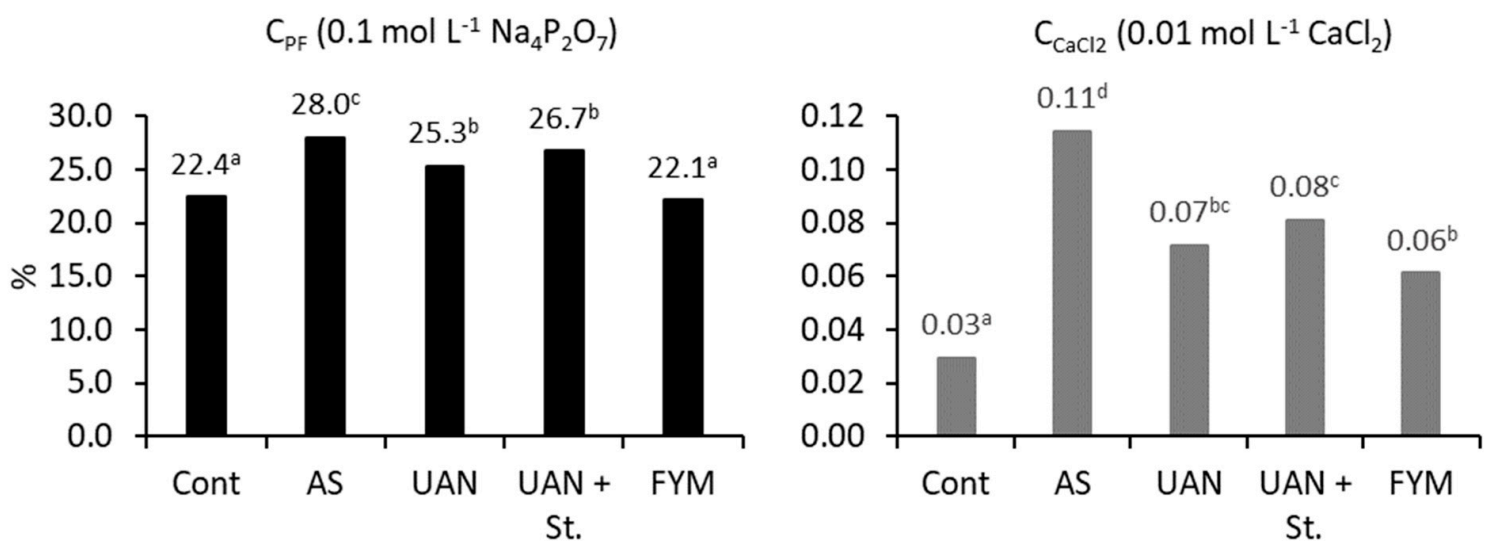

Figure 3. Ratio of extractable carbon of total soil organic matter carbon ( $\left.\mathrm{C}_{\mathrm{SOM}}\right)$; topsoil; different letters behind the values mean significant differences among investigated treatments (Tukey test; $p<0.05$ ); number of replications per treatment $n=4$.

$$
\mathrm{C}_{\mathrm{CaCl} 2}\left(0.01 \mathrm{~mol} \mathrm{~L}^{-1} \mathrm{CaCl}_{2}\right)
$$
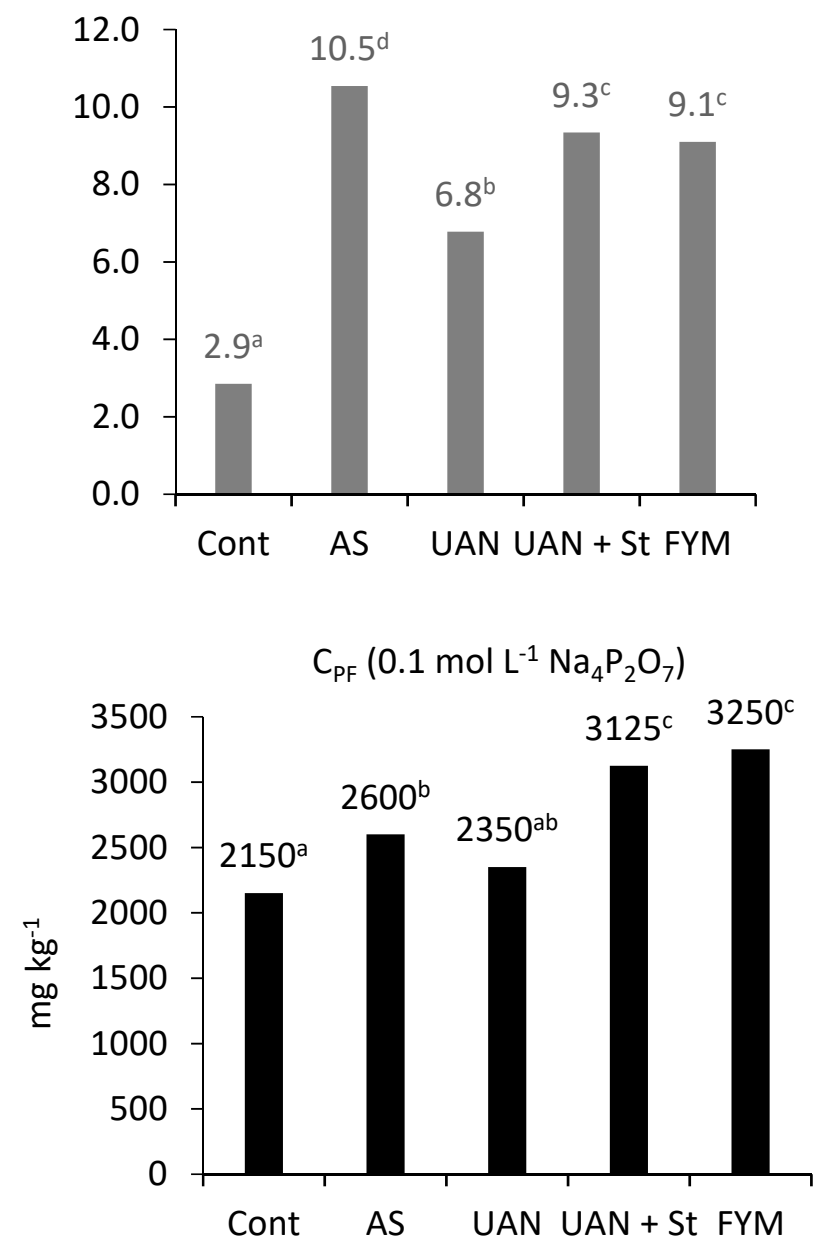

Figure 4. Content of extractable carbon determined with different extraction procedures; topsoil; different letters behind the values mean significant differences among investigated treatments (Tukey test; $p<0.05$ ); number of replications per treatment $n=4$.

Over the period of 26 years, a significant decrease of the $\mathrm{C}_{\mathrm{HA}}$ content in the control and AS plots (by 50\%) was observed. By contrast, the farmyard manure treatment showed significantly higher $\mathrm{C}_{\mathrm{HA}}$ compared to other treatments. A similar tendency may be observed in case of the $\mathrm{C}_{\mathrm{HA}} / \mathrm{C}_{\mathrm{FA}}$ ratio (Figure 5). 

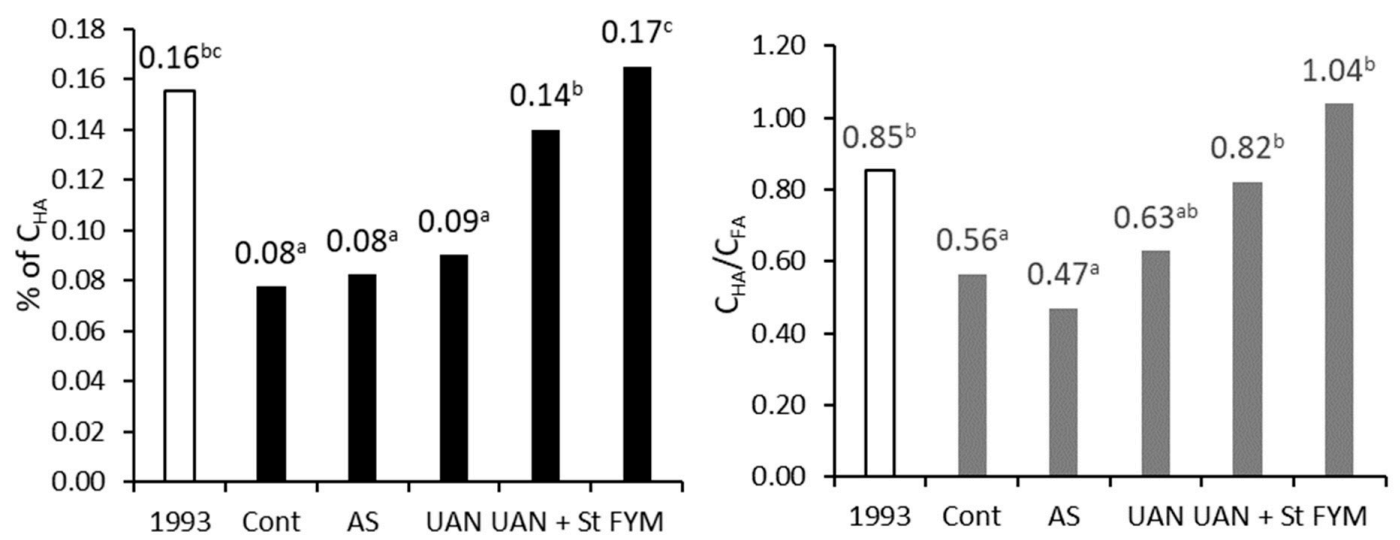

Figure 5. Content of humic acids $\left(\mathrm{C}_{\mathrm{HA}}\right)$ and their ratio to fulvic acids $\left(\mathrm{C}_{\mathrm{FA}}\right)$; topsoil; different letters behind the values mean significant differences among investigated treatments (Tukey test; $p<0.05$ ); number of replications per treatment $n=4$.

\subsection{The Quality of Post-Harvest Residues}

Mineral $\mathrm{N}$ fertilization destabilized organic matter in the soil. This was demonstrated by values of the $\mathrm{C}_{\mathrm{SOM}} / \mathrm{N}_{\mathrm{t}}$ ratio in topsoil and subsoil (Figure 6). In topsoil, a significant decrease in the $\mathrm{C}_{\mathrm{SOM}} / \mathrm{N}_{\mathrm{t}}$ ratio was observed in AS and UAN treatments compared to the control. The reason for the change in this ratio is mainly a decrease of $\mathrm{C}_{\mathrm{SOM}}$ content in mineral $\mathrm{N}$ fertilization treatments, because $\mathrm{N}_{\mathrm{t}}$ content was the same in all three compared treatments $(0.10 \%)$. In the subsoil, this difference was not significant, but there was a real tendency to its decrease. It may be presumed that during subsequent years the differences will also become more significant. The highest $\mathrm{C}_{\mathrm{SOM}} / \mathrm{N}_{\mathrm{t}}$ ratio was always observed in the farmyard manure treatment.

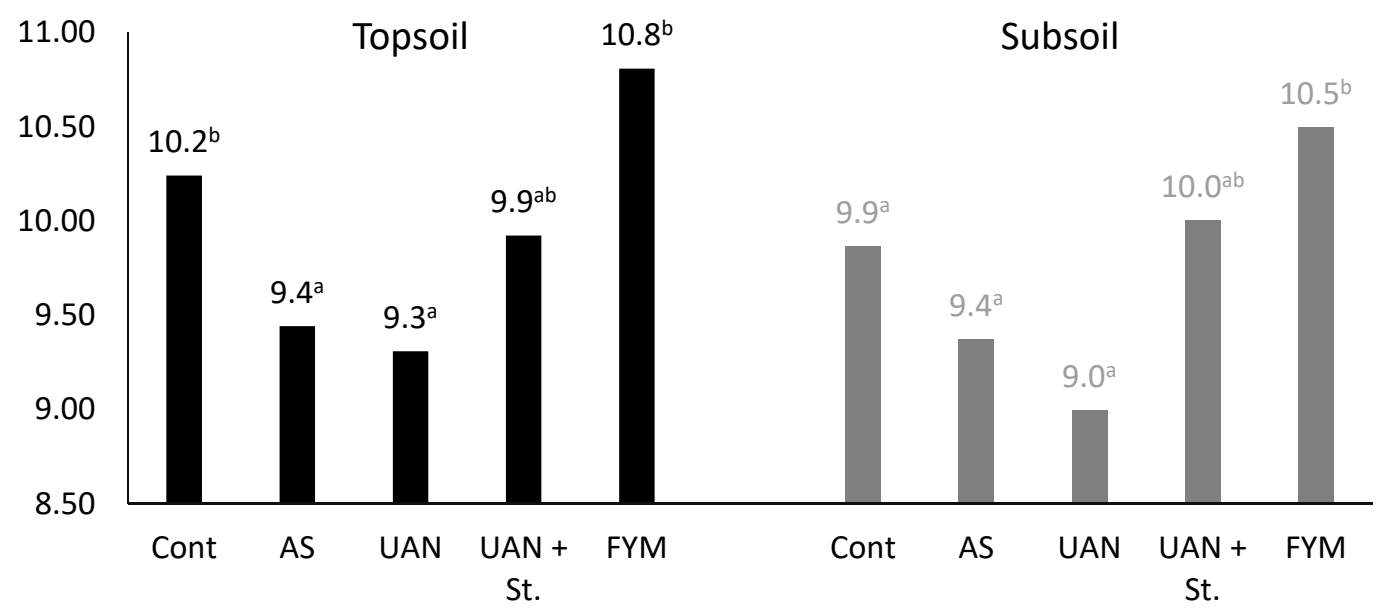

Figure 6. Soil organic matter carbon $\left(\mathrm{C}_{\mathrm{SOM}}\right) /$ soil total nitrogen $\left(\mathrm{N}_{\mathrm{t}}\right)$ ratio in topsoil and subsoil; different letters behind the values mean significant differences among investigated treatments (Tukey test; $p<0.05$ ); number of replications per treatment $n=4$.

The reason for the $\mathrm{C}_{\mathrm{SOM}} / \mathrm{N}_{\mathrm{t}}$ ratio change may be inferred from the increased mineral $\mathrm{N}$ content in soil and, furthermore, from the quality of the tilled post-harvest residues (stubble) and root biomass (Figure 7). In stubble, the carbon/nitrogen $(\mathrm{C} / \mathrm{N})$ ratio in control plots was 315/1, in AS it was 107/1, and in UAN 88/1, respectively. The lowest (70/1) value was determined in the UAN + St treatment, which corresponds to the highest $\mathrm{N}$ fertilization intensity within this treatment. Similarly high differences among the treatments were observed in the analysis of roots in topsoil; the highest ratio was also observed in the control treatment $(C / N=123 / 1)$, whereas it was very low in the mineral $\mathrm{N}$ 
treatments $(\mathrm{C} / \mathrm{N}=49 / 1)$. These differences reflect the fact that both root biomass and plant residues were more stable in control plots compared to $\mathrm{N}$ fertilization.

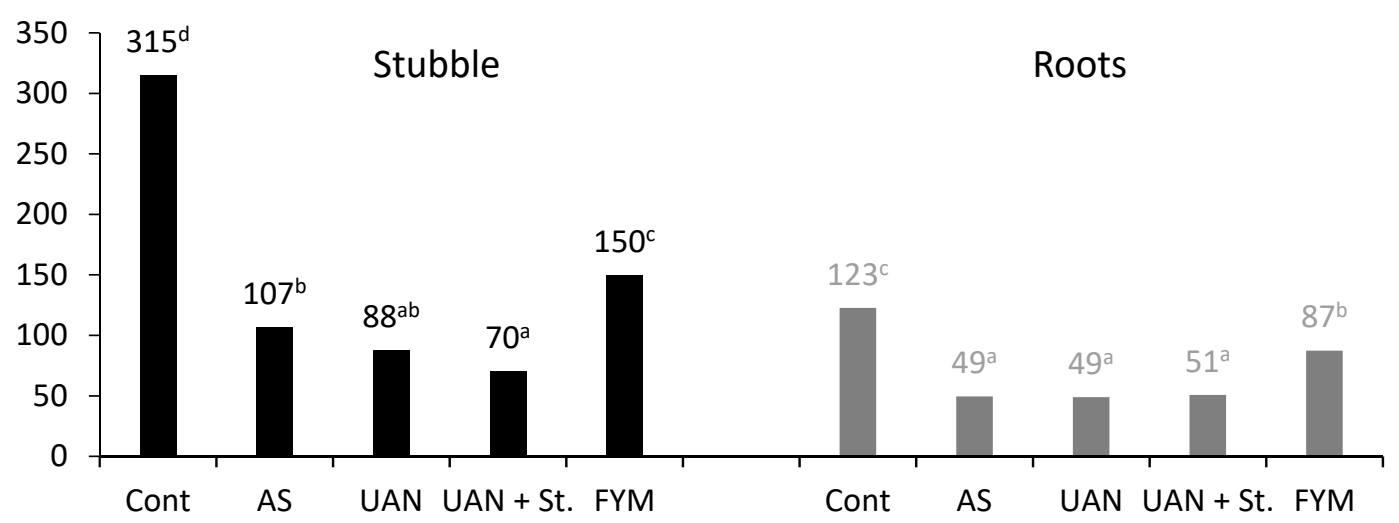

Figure 7. Carbon/nitrogen $(\mathrm{C} / \mathrm{N})$ ratio in crop residues of maize; different letters behind the values mean significant differences among investigated treatments (Tukey test; $p<0.05$ ); number of replications per treatment $n=4$.

Figure 8 demonstrates that this was due to post-harvest residues and roots that supplied $90-100 \%$ more carbon in mineral $\mathrm{N}$ treatments compared to the control. The highest amount of post-harvest residues was in the farmyard manure treatment (stubble: $360 \mathrm{~kg} \mathrm{C} \mathrm{ha}^{-1}+$ roots: $768 \mathrm{~kg} \mathrm{C} \mathrm{ha}^{-1}=1128 \mathrm{~kg} \mathrm{C} \mathrm{ha}^{-1}$ ).

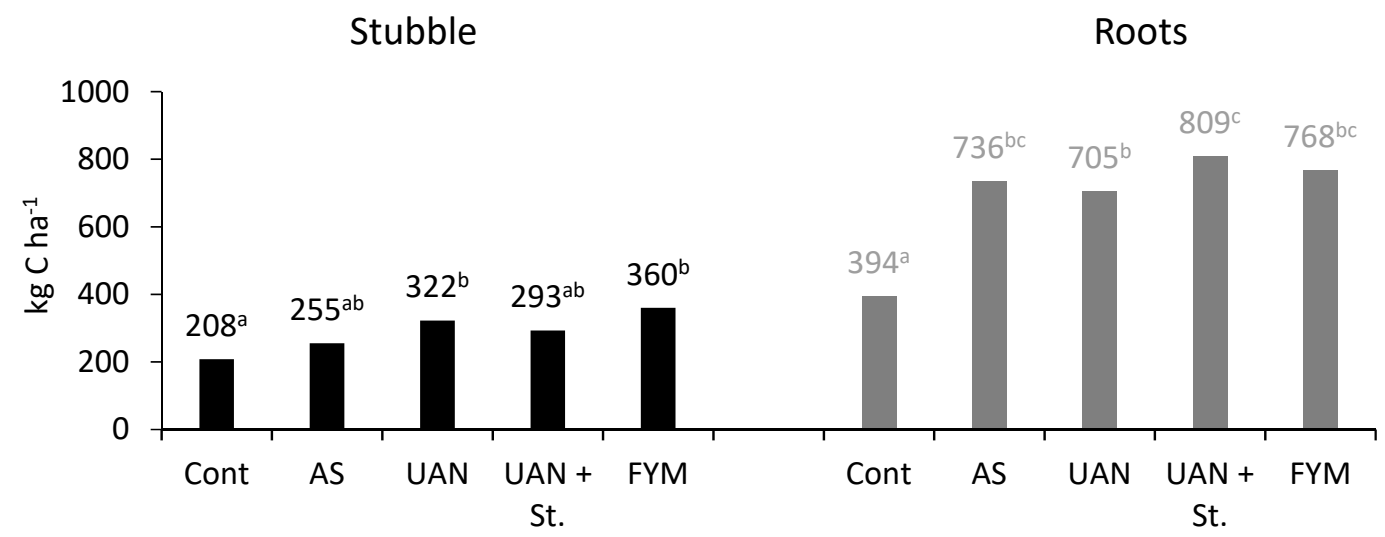

Figure 8. Carbon contents in crop residues of maize; different letters behind the values mean significant differences among investigated treatments (Tukey test; $p<0.05$ ); number of replications per treatment $n=4$.

\section{Discussion}

The luvisols comprise over 500-600 million ha worldwide and are situated mainly in temperate regions such as in the East European Plains and parts of West Siberian Plain, the North East of the United States of America and Central Europe, but also in the Mediterranean region and southern Australia. Most luvisols are fertile soils and suitable for a wide range of agricultural uses [22]. The worldwide area used for maize forage is about 16.8 million ha [23]. Our results, which are presenting the soil carbon transformations in the maize monoculture cropped on luvisol also provide information that could be useful not only for regional purposes. Similar results can be expected in similar soil conditions by cropping the silage maize in long-term monoculture.

The average yield of the harvested biomass in the control plots over a period of 26 years was $8.84 \mathrm{t} \mathrm{DM} \mathrm{ha}^{-1}$ year $^{-1}$, which represents $3755 \mathrm{~kg} \mathrm{C} \mathrm{ha}^{-1}$ year $^{-1}$. In fertilized plots, the biomass yield was $40-58 \%$ greater compared to the control. Although the intensity of mineral nitrogen fertilization (120 kg N ha ${ }^{-1}$ year $^{-1}$ ) corresponded to the yields obtained and from the long-term perspective, it was in compliance with $\mathrm{N}$ uptake by plants, mineral $\mathrm{N}$ resulted in a $\mathrm{C}_{\mathrm{SOM}}$ decrease in soil. During the experimental period (26 years), the most significant decrease was that of $\mathrm{C}_{\mathrm{SOM}}$ in the AS treatment 
(26\%) and the UAN treatment (25\%). It is almost alarming that in an annual application of wheat straw $\left(5 \mathrm{t} \mathrm{DM} \mathrm{ha}^{-1}=2140 \mathrm{~kg} \mathrm{C} \mathrm{ha}^{-1}\right) \mathrm{C}_{\mathrm{SOM}}$ also decreased (by $8 \%$ ). It is obvious that straw is relatively quickly mineralized after its incorporation into the soil [24-27]. Due to this fact it is clear that cereal straw application itself cannot improve the soil organic matter content and quality. This was confirmed in our experiments by the aforementioned decrease of $\mathrm{C}_{\mathrm{SOM}}$ at this treatment.

The annual average dose of manure was $18.7 \mathrm{t} \mathrm{ha}^{-1}$, which was above average, but not extremely high. Cattle manure with a $\mathrm{C} / \mathrm{N}$ ratio of $13.4 / 1$ was used. The relatively low $\mathrm{C} / \mathrm{N}$ ratio in manure fully corresponds with stable technologies currently used in CR. This means a decrease in the $\mathrm{C} / \mathrm{N}$ ratio compared to the past when the standard values were 15-18/1. However, manure application contributed to a significant increase in the $\mathrm{C}_{\mathrm{SOM}}$ values (from $1.26 \%$ to $1.46 \%$ ). A significantly positive effect of manure may also be observed in the study of Menšík et al. [4]. Schmidt et al. [28] reported an increase of $\mathrm{C}_{\mathrm{SOM}}$ values by $32 \%$ (from $1.24 \%$ to $1.64 \%$ ) at a dose of $12 \mathrm{t} \mathrm{ha}^{-1}$ year $^{-1}$ and a period of 50 years for rye cultivated in a monoculture. The importance of the $\mathrm{C} / \mathrm{N}$ ratio is evident, but the quality of the incorporated organic matter is important as well. For example, in the UAN + St treatment, the resulting ratio in the fertilizers applied, $\mathrm{C} / \mathrm{N}=14.6 / 1$, was higher compared to manure, but it did not result in a $\mathrm{C}_{\mathrm{SOM}}$ increase. Manure contains significantly more stable organic matter than straw and thus helps to control $\mathrm{C}_{\mathrm{SOM}}$ stability.

Furthermore, in the control plots, a decrease of $\mathrm{C}_{\mathrm{SOM}}$ content was observed, namely by $22 \%$, which corresponds to losses of $485 \mathrm{~kg} \mathrm{C} \mathrm{ha}^{-1}$ year $^{-1}$. In the case of the AS treatment, this represents $571 \mathrm{~kg} \mathrm{C} \mathrm{ha}^{-1}$ year ${ }^{-1}$ compared to UAN with $537 \mathrm{~kg} \mathrm{~N} \mathrm{ha}^{-1}$ year $^{-1}$. These values do not include $\mathrm{C}$ losses due to mineralization of post-harvest residues. The values are high but fully correspond with the results of [2] concerning long-term silage maize cultivation. These authors reported average losses of $530 \mathrm{~kg} \mathrm{C} \mathrm{ha}^{-1}$ year $^{-1}$ in an unfertilized plot and $550 \mathrm{~kg} \mathrm{C} \mathrm{ha}^{-1}$ year $^{-1}$ in a fertilized one. A decrease of $\mathrm{C}_{\mathrm{SOM}}$ content in maize monoculture was also documented by [7,9]. A $\mathrm{C}_{\mathrm{SOM}}$ content increase was reported mostly in maize cultivated for grain [6,10]. For example, Liang and MacKenzie [29] recorded increased $\mathrm{C}_{\mathrm{SOM}}$ content in topsoil by $18 \%$ after six-year maize cultivation for grain. Basically, silage maize cultivation results in a small amount of aboveground post-harvest residues (stubble). In the present study, the height of stubble was about $10 \mathrm{~cm}$. The carbon content in stubble ranged between $208 \mathrm{~kg} \mathrm{C} \mathrm{ha}^{-1}$ (control) up to $360 \mathrm{~kg} \mathrm{C} \mathrm{ha}^{-1}$ (manure). This is in good agreement with the assessment of [15] who reported a value of $290 \mathrm{~kg} \mathrm{C} \mathrm{ha}^{-1}$.

To evaluate $C$ balance, it is necessary to determine the number of roots. In our experiments, the amount of carbon in roots was determined after harvest. Determined values were in a range of $394 \mathrm{~kg} \mathrm{C} \mathrm{ha}^{-1}$ year-1 (control) up to $809 \mathrm{~kg} \mathrm{C} \mathrm{ha}^{-1}$ year-1 $^{-1}$ UAN + St). Balesdent and Balabane [15] determined the number of roots at the level of $12 \%$ of the aboveground biomass. Using this model for calculations, determined values were in the range of $476 \mathrm{~kg} \mathrm{C} \mathrm{ha}^{-1}$ year $^{-1}$ (control) up to $738 \mathrm{~kg} \mathrm{C} \mathrm{ha}^{-1}$ year $^{-1}(\mathrm{UAN}+\mathrm{St}$ ). The aforementioned calculations considered the whole root biomass, including subsoil. The experiments of [2] demonstrated a ratio of root biomass and root exudates of $18 \%$ compared to aboveground biomass. Using this model of calculation, the determined values were in the interval from $870 \mathrm{~kg} \mathrm{C} \mathrm{ha}^{-1}$ year $^{-1}$ (control) up to $1349 \mathrm{~kg} \mathrm{C} \mathrm{ha}^{-1}$ year $^{-1}$ (UAN + St). The values for the topsoil and subsoil calculated according to Rasse et al. [10] were as follows: $63 \%$ topsoil, $37 \%$ subsoil. The comparison of calculated values and those obtained in our measurements show good agreement (Table 1). Both methods show the lowest values in the control and the highest in the $\mathrm{UAN}+\mathrm{St}$ treatment. To conclude, the values determined by measurements were about $10 \%$ lower than the calculated ones. There are several possible reasons: (i) the amount of roots was determined after 26 years of monoculture. As reported by [28], in the case of long-term monoculture, the amount of roots and rhizodeposition decrease by as much as 30\%; (ii) the calculations by [2] also comprise exudate carbon that was not determined in our experiments; and (iii) the highest difference among the calculated and measured values was observed mostly in the control; in this variant, a significant tendency to lower yields of aboveground biomass and, thus, roots were observed over the years. For calculation models, the average biomass yield value over the period of 26 years was used. 
Studying the root biomass in field conditions always involves error, but it is possible to assess 30 the $\mathrm{C}$ ratio using the values determined directly in our study (Table 2). It is evident that the amount of post-harvest residues in silage maize is very small (stubble: $208-360 \mathrm{~kg} \mathrm{C} \mathrm{ha}^{-1}$; roots $394-809 \mathrm{~kg} \mathrm{C} \mathrm{ha}^{-1}$ ) and cannot replace the losses due to $\mathrm{C}_{\mathrm{SOM}}$ mineralization [2]. In post-harvest residues, the $\mathrm{C} / \mathrm{N}$ ratio was observed (Figure 7). The results obtained prove that root biomass as well as the stubble residues were more stable (higher $\mathrm{C} / \mathrm{N}$ ratio) in control plots than in mineral $\mathrm{N}$-fertilized ones. Additionally, the manure treatment showed a statistically significant increase in the $\mathrm{C} / \mathrm{N}$ ratio compared to the mineral $\mathrm{N}$ fertilization. Similar to our experiments, [2] also identified a significantly higher $\mathrm{C} / \mathrm{N}$ ratio in stubble (197/1) compared to roots (28/1).

$\mathrm{N}$ applied in mineral fertilizers showed a significant decrease in the $\mathrm{C}_{\mathrm{SOM}} / \mathrm{N}_{\mathrm{t}}$ ratio in topsoil, which confirms the hypothesis that mineral $\mathrm{N}$ fertilization leads to soil organic matter (SOM) destabilization. Contrariwise, manure treatment showed an increase in this ratio.

The overall $\mathrm{C}$ ratio (Table 2) clearly shows that the lowest carbon losses due to mineralization were recorded in the control $\left(1087 \mathrm{~kg} \mathrm{ha}^{-1}\right.$ year $\left.^{-1}\right)$. Contrariwise, the highest losses were determined in the UAN + St treatment-3415 $\mathrm{kg} \mathrm{C} \mathrm{ha}^{-1}$ year $^{-1}$. The evaluation of carbon losses due to the mineralization process related to the total carbon amount in the harvested biomass is very interesting. The results clearly show that the control $(28.9 \%)$, AS $(29.7 \%)$, and UAN $(28.4 \%)$ treatments do not differ significantly. The application of organic fertilizers turns this ratio significantly more negative: UAN + St $(57.6 \%)$ and manure (41.1\%) (Table 2). High losses of $C$ in soil highlight the importance of this research and at the same time the necessity of a complex approach to its solution.

The relationship between the amount of extractable carbon $\left(\mathrm{C}_{\mathrm{CaCl} 2}, \mathrm{C}_{\mathrm{PF}}\right)$ and the total amount of $\mathrm{C}_{\mathrm{SOM}}$ documents the fact that the control plots and farmyard manure treatment had more stable organic matter and consequently, a lower intensity of mineralization [29]. The highest values were recorded in the AS treatment- the ratio of $\mathrm{C}_{\mathrm{CaCl} 2} / \mathrm{C}_{\mathrm{SOM}}$ was $0.11 \%$ and that of $\mathrm{C}_{\mathrm{PF}} / \mathrm{C}_{\mathrm{SOM}} 28 \%$. Similarly, a very low extraction strength $\left(0.01 \mathrm{~mol} \mathrm{~L}^{-1} \mathrm{CaCl}_{2}\right)$ was also determined in our previous experiments at different sites [30]. In contrast, a lower ratio of $\mathrm{C}_{\mathrm{PF}} / \mathrm{C}_{\mathrm{SOM}}$ was recorded in our trials compared to the results of Ellerbrock and Kaiser [31]. In their trials, about $40 \%$ of $\mathrm{C}_{\mathrm{SOM}}$ was extracted while in our trials it was only $22-28 \%$. Furthermore, [4] used the $\mathrm{C}_{\mathrm{PF}} / \mathrm{C}_{\mathrm{SOM}}$ ratio to assess the stability of $\mathrm{SOM}$, suggesting that the higher this ratio is, the less stable the $\mathrm{C}_{\mathrm{SOM}}$. Similar to our experiments, [4] also determined the lowest value in the manure treatment (27.6\%) and the highest in the mineral nitrogen, phosphorus and potassium (NPK) treatment (34.7\%). Over the period of 26 years, $\mathrm{C}_{\mathrm{SOM}}$ degradation occurred in almost all treatments, except farmyard manure. Both the content of $\mathrm{C}_{\mathrm{HA}}$ and the $\mathrm{C}_{\mathrm{HA}} / \mathrm{C}_{\mathrm{FA}}$ decreased. This process was the fastest in the AS treatment. It is evident that manure helps to increase the content of $\mathrm{C}_{\mathrm{HA}}$ as well as its ratio in $\mathrm{C}_{\mathrm{HS}}$ [4]. In the UAN + St treatment, the content of $\mathrm{C}_{\mathrm{HA}}$ did not increase; the $\mathrm{C}_{\mathrm{HA}} / \mathrm{C}_{\mathrm{FA}}$ did not improve, even with the application of high doses of wheat straw.

Using the analyses of ${ }^{13} \mathrm{C} /{ }^{12} \mathrm{C}$ allowed us to determine the ratio of $\mathrm{C}_{4}$ in the $\mathrm{C}_{\mathrm{SOM}}$ and $\mathrm{C}_{4}$ ratio in different extractable fractions. This was realized only for the mineral fertilizing treatments for two reasons: (i) the ${ }^{13} \mathrm{C} /{ }^{12} \mathrm{C}$ was not evaluated at organic inputs (FYM, straw), because we have not the data for ${ }^{13} \mathrm{C} /{ }^{12} \mathrm{C}$ in input materials; (ii) the results originate from the long-term experiments with maize monoculture, which allows us to make a reliable evaluation. It was evident that the $\mathrm{C}_{4}$ ratio was higher in the fertilized plots compared to the control (control 8.10\%, AS 10.3\%, UAN 11.8\%). The higher ratio in fertilized plots is reported by many authors [6-9]. However, the $\mathrm{C}_{4}$ ratios determined in these studies differ significantly. There is a significant influence of the monoculture duration-from six years [11], up to 40 years [9]. The purpose of cultivation (grain/silage) is also very important. Our values are in good compliance with [9], who reported a $\mathrm{C}_{4}$ ratio in $\mathrm{C}_{\mathrm{SOM}}$ of $9.5 \%$ in the unfertilized control and $14.1 \%$ in the fertilized treatments. Our experiments and the work by [9] focused on silage maize, where almost all aboveground biomass is taken off the field. A similarly low $\mathrm{C}_{4} / \mathrm{C}_{\mathrm{SOM}}$ ratio $(13 \%)$ was also determined by [10]. Ellerbrock and Kaiser [31] also determined 14.2\%. By contrast, [6] published results where $\mathrm{C}_{4}$ represented $60 \%$ of $\mathrm{C}_{\mathrm{SOM}}$ in topsoil. However, it was in long-term grain-maize cultivation. Our results show that the $\mathrm{C}_{4}$ ratio in the $\mathrm{C}_{\mathrm{SOM}}$ of the subsoil is significantly lower. In the 
control, it was 5.5\%, in AS 7.9\%, and in UAN 6.0\%, respectively. Similarly low $\mathrm{C}_{4}$ ratios in $\mathrm{C}_{\mathrm{SOM}}$ $(5-10 \%)$ were recorded for subsoil in the studies of $[8,9]$.

A significantly higher $\mathrm{C}_{4}$ ratio compared to $\mathrm{C}_{\mathrm{SOM}}$ was recorded in the hydrolysable fractions of organic compounds $\left(\mathrm{C}_{\mathrm{DOC}}\right)$. The $0.01 \mathrm{~mol} \mathrm{~L}^{-1} \mathrm{CaCl}_{2}$ extraction solution had a $\mathrm{C}_{4}$ ratio in $\mathrm{C}_{\mathrm{CaCl} 2}$ in the interval of $17.9-20.7 \%$ and the $0.1 \mathrm{~mol} \mathrm{~L}^{-1} \mathrm{Na}_{4} \mathrm{P}_{2} \mathrm{O}_{4}$ extractable fraction was in the interval of $10.20-14.60 \%\left(\mathrm{C}_{4}\right.$ ratio in $\left.\mathrm{C}_{\mathrm{PF}}\right)$. It was evident that the weaker the extraction agent, the higher the ratio of maize carbon. Similarly, Ellerbrock and Kaiser [31] determined a ratio of $22 \% \mathrm{C}_{4}$ for water extractable carbon and $16 \% \mathrm{C}_{4}$ for $\mathrm{C}_{\mathrm{PF}}$. Higher ratios than those determined in our experiment have been reported, e.g., by [5] ratio $34 \% \mathrm{C}_{4}$ in $\mathrm{C}_{\mathrm{DOC}}$; [12] ratio 30\%; [9] ratio 5-30\%. A very high ratio of $\mathrm{C}_{4}$ in $C_{\text {DOC }}(29-54 \%)$ was reported by [5]; however, it was in long-term grain-maize cultivation. In our experiments, the ratio of $\mathrm{C}_{4}$ in $\mathrm{C}_{\mathrm{DOC}}$ was always higher in fertilized plots compared to the control with no fertilization, which complies with previous results. The results further show that fertilization increases the amount of easily extractable and thus less stable $C$ fraction [13].

Statistically conclusive differences in the content of $\mathrm{C}_{3}$ between control and $\mathrm{N}$-fertilized plots document the fact that AS or UAN applications result in stronger mineralization of original and stable organic matter compared to a non-fertilized control (Table 3). The increase of $C_{4}$ content in these treatments does not compensate for the decrease of $C_{3}$ content; the result is a tendency to decrease total $\mathrm{C}_{\text {SOM }}$ content [2,7]. This process also takes place in the subsoil, but less dynamically. Fertilized plots in our experiments had about $9 \%$ lower $\mathrm{C}_{3}$ content in topsoil.

\section{Materials and Methods}

\subsection{Field Experiments}

Long-term stationary field trials with maize monoculture were set up at the Czech University of Life Sciences experimental site Červený Újezd in 1993. Maize was grown for silage. The characteristics of the site are shown in Table 4.

Table 4. Basic description of investigated location; $\mathrm{C}_{\mathrm{SOM}}$-soil organic matter carbon.

\begin{tabular}{|c|c|}
\hline GPS Coordinates & $50^{\circ} 4^{\prime} 22^{\prime \prime} \mathrm{N} ; 14^{\circ} 10^{\prime} 19^{\prime \prime} \mathrm{E}$ \\
\hline Altitude (m above sea level) & 410 \\
\hline Mean annual temperature $\left({ }^{\circ} \mathrm{C}\right)$ & 7.7 \\
\hline Mean annual precipitation (mm) & 493 \\
\hline Soil type [32] & Haplic Luvisol \\
\hline Soil texture [ 32] & Loam \\
\hline Clay $(\%)(<0.002 \mathrm{~mm})$ & 5.4 \\
\hline Silt (\%) (0.002-0.05 mm) & 68.1 \\
\hline Sand $(\%)(0.05-2 \mathrm{~mm})$ & 26.5 \\
\hline Bulk density $\left(\mathrm{g} \mathrm{cm}^{-3}\right)$ topsoil [33] & 1.47 \\
\hline Bulk density $\left(\mathrm{g} \mathrm{cm}^{-3}\right)$ subsoil [33] & 1.55 \\
\hline $\mathrm{C}_{\mathrm{SOM}}(\%)$ & 1.26 \\
\hline $\mathrm{pH}\left(\mathrm{CaCl}_{2}\right)$ & 6.5 \\
\hline Cation exchange capacity $\left(\mathrm{mmol}_{(+)} \mathrm{kg}^{-1}\right)$ & 118 \\
\hline
\end{tabular}

The size of individual experimental plots was $170 \mathrm{~m}^{2}(20 \mathrm{~m}$ length $\times 8.5 \mathrm{~m}$ width) and the size of harvested plots $20 \mathrm{~m}^{2}$ (two middle rows of the experimental plot). Each treatment (experimental plot) was conducted in four replications in a randomized design. Nitrogen was applied in the same dose (120 kg N ha ${ }^{-1}$ year ${ }^{-1}$ ) using ammonium sulfate (AS), urea ammonium nitrate (UAN) and farmyard manure (FYM), except for the unfertilized control plots (Cont) and treatment UAN with straw (UAN + St) (Table 5). Nitrogen fertilizers were applied in spring, before maize sowing. In the $\mathrm{UAN}+\mathrm{St}$ treatment, wheat straw $\left(5 \mathrm{t}\right.$ dry matter $(\mathrm{DM}) \mathrm{ha}^{-1}$ ) was applied just before the autumn 
tillage. Similarly, FYM was applied in the autumn and immediately incorporated with ploughing to minimize nitrogen losses. The amount of FYM corresponded to $120 \mathrm{~kg} \mathrm{~N} \mathrm{ha}^{-1}$ (always according to FYM nitrogen content analysis).

Table 5. Fertilizing design of the experiment; AS-ammonium sulfate, UAN-urea ammonium nitrate, UAN + st-urea ammonium nitrate + straw, FYM-farmyard manure, DM-dry matter, $\mathrm{C}$-carbon, $\mathrm{N}$-nitrogen.

\begin{tabular}{|c|c|c|c|c|c|c|}
\hline Treatment & $\begin{array}{l}\mathrm{kg} \mathrm{N} \mathrm{ha}^{-1} \\
\text { year }^{-1}\end{array}$ & $\begin{array}{l}\text { Organic Fertilizer } \\
\left(\text { (kg DM ha year }^{-1}\right)\end{array}$ & $\begin{array}{l}\text { C Content } \\
\text { in DM (\%) }\end{array}$ & $\begin{array}{c}\text { C Supplied } \\
\left(\mathrm{kg} \mathrm{ha}^{-1} \text { year }^{-1}\right)\end{array}$ & $\begin{array}{l}\text { C Supplied during } \\
26 \text { Years }\left(\mathrm{kg} \mathrm{ha}^{-1}\right)\end{array}$ & $\begin{array}{l}\mathrm{C} / \mathrm{N} \text { in Org. } \\
\text { Fert. }\end{array}$ \\
\hline Control & - & - & - & - & - & - \\
\hline AS & 120 & - & - & - & - & - \\
\hline UAN & 120 & - & - & - & - & - \\
\hline $\mathrm{UAN}+\mathrm{St}$ & $120+33.5^{1}$ & 5000 & 42.8 & 2140 & 55,640 & $79.3 / 1$ \\
\hline FYM & 120 & 5752 & 27.9 & 1603 & 41,678 & $13.4 / 1$ \\
\hline
\end{tabular}

${ }^{1} \mathrm{~N}$ content in wheat straw; after application of UAN to UAN + St treatment the final C/N ratio changed to 14.6:1.

All aboveground biomass was harvested and removed from the harvested plot, except for about $10 \mathrm{~cm}$ stubble. The roots were extracted by the sampling of topsoil blocks (area $40 \times 40 \mathrm{~cm} ; 30 \mathrm{~cm}$ depth; 4 subsamples per plot) and were subsequently washed and separated.

Soil samples (topsoil from 0-30 $\mathrm{cm}$ and subsoil $30-60 \mathrm{~cm}$ depth) were taken up after maize harvest from twelve sampling points per plot, subsequently, mixed, sieved through $5 \mathrm{~mm}$ mesh and frozen. To the further described soil analysis, samples from the years 1993 and 2018 were thawed, air-dried, sieved through $2 \mathrm{~mm}$ mesh and analyzed (except for $\mathrm{CaCl}_{2}$ extraction, where the fresh soil samples were analyzed). The $\mathrm{C}_{\text {SOM }}$ content was determined in the samples taken up in both years (1993 and 2018). The remaining soil analysis proceeded only in the samples taken up in 2018.

\subsection{Analysis}

A solution of $0.01 \mathrm{~mol} \mathrm{~L}^{-1} \mathrm{CaCl}_{2}\left(\mathrm{C}_{\mathrm{CaCl} 2}\right)$ was used (1:10,w/v) to determine one of the less stable soil $\mathrm{C}_{\mathrm{CaCl}}$ fractions. The content of $\mathrm{C}_{\mathrm{CaCl}}$ was determined in fresh soil samples by segmental flow-analysis using the infrared detection on a Skalar ${ }^{\text {plus }}$ System (Skalar, Breda, The Netherlands).

Fractionation of humic substances $\left(\mathrm{C}_{\mathrm{HS}}\right)$ was undertaken according to the [34] method to obtain the pyrophosphate extractable fraction $\left(\mathrm{C}_{\mathrm{PF}}\right)$, which represents the sum of the carbon in humic acids $\left(\mathrm{C}_{\mathrm{HA}}\right)$ and fulvic acids $\left(\mathrm{C}_{\mathrm{FA}}\right)$. In brief, $\mathrm{C}_{\mathrm{HA}}$ and $\mathrm{C}_{\mathrm{FA}}$ were extracted from a $5 \mathrm{~g}$ soil sample with a mixture of $0.1 \mathrm{~mol} \mathrm{~L}^{-1} \mathrm{NaOH}$ and $0.1 \mathrm{~mol} \mathrm{~L}^{-1} \mathrm{Na}_{4} \mathrm{P}_{2} \mathrm{O}_{7}(1: 20, v / v)$ solution. Carbon of humic substances $\mathrm{C}_{\mathrm{HS}}$ and $\mathrm{C}_{\mathrm{HA}}$ was determined by an oxidimetric titration method. The content of $\mathrm{C}_{\mathrm{FA}}$ was calculated as the difference between $\mathrm{C}_{\mathrm{HS}}$ and $\mathrm{C}_{\mathrm{HA}}$. The degree of humification was calculated as the ratio of $\mathrm{C}_{\mathrm{HS}}$ content and $\mathrm{C}_{\mathrm{SOM}}$ content multiplied by 100 [4].

Stable isotope $\delta^{13} \mathrm{C}$ analyses were performed by flash combustion in a Fisons 1108 elemental analyzer coupled with an isotope ratio mass spectrometer Delta V Advantage (ThermoFisher, Bremen, Germany) in a continuous flow regime. The sample size was adjusted to contain a sufficient amount of carbon. Results are reported as $\delta^{13} \mathrm{C}$ values (in per mil \%o) relative to Vienna Pee-Dee Belemite (V-PDB). International standards NBS $22(-30.031 \%$ o), IAEA-CH-7 (-32.151\%o), and in-house standard soil $(-27.80 \%$ o) were used as reference material. The long-term reproducibility was better than $0.15 \%$. ${ }^{13} \mathrm{C} /{ }^{12} \mathrm{C}$ isotope ratios were expressed as $\delta^{13} \mathrm{C}$ values.

$$
\delta^{13} \mathrm{C}(\% \mathrm{oo})=\left[\left(\delta_{\mathrm{sam}} / \delta_{\mathrm{std}}\right)-1\right] \times 10^{3},
$$

where $\delta_{\text {sam }}={ }^{13} \mathrm{C} /{ }^{12} \mathrm{C}$ ratio of sample, and $\delta_{\text {std }}={ }^{13} \mathrm{C} /{ }^{12} \mathrm{C}$ ratio of the reference standard (PDB). The $\delta^{13} \mathrm{C}$ values of dissolved organic carbon (DOC) were determined by the method of Buzek et al. [35]. In brief, the solution was acidified with diluted phosphoric acid to remove bicarbonates, and further concentrated by evaporation (at $50{ }^{\circ} \mathrm{C}$ ) for DOC $\delta^{13} \mathrm{C}$ measurements (Fisons 1108 and Delta V with NBS 22 as internal reference). 
The content of total organic carbon and nitrogen in air-dried soils, in farmyard manure, and in plants was determined using oxidation on a CNS analyzer (Elementar Vario Macro, Elementar Analysensysteme, Hanau-Frankfurt am Main, Germany).

Data were processed using basic tests for normal distribution and subsequently one-way analysis of variance (ANOVA, Tukey test; $p<0.05$ ) using the STATISTICA 12 (Dell-StatSoft Inc., Austin, TX, USA) program.

\section{Conclusions}

Soil organic matter carbon $\left(\mathrm{C}_{\mathrm{SOM}}\right)$ compounds' degradation was observed in long-term field experiments with silage maize monoculture. Over a relatively short period of 26 years, the content of carbon in topsoil decreased by $22 \%$ in control plots compared to $26 \%$ in treatments fertilized with mineral N. It is almost alarming that in an annual application of wheat straw $\left(5 \mathrm{t} \mathrm{DM} \cdot \mathrm{ha}^{-1}\right) \mathrm{C}_{\mathrm{SOM}}$ also decreased (by $8 \%$ ). It is obvious that straw was relatively quickly mineralized after its incorporation into the soil. By contrast, the application of farmyard manure resulted in a $\mathrm{C}_{\mathrm{SOM}}$ increase of $16 \%$.

The ratio of carbon produced by maize from total topsoil $\mathrm{C}_{\mathrm{SOM}}$ content ranged between $8.1-11.8 \%$. In plots with mineral $\mathrm{N}$ fertilization, this ratio was always higher than in the unfertilized control plots. The weaker the soil extraction agent, the higher ratio of maize carbon, which shows that maize produced mostly unstable carbon compounds. Furthermore, mineral $\mathrm{N}$ application resulted in stronger mineralization of original and stable organic matter compared to the unfertilized control. However, the increase of maize carbon content in fertilized plots did not compensate the decrease of "old" organic matter. As a result, a tendency of decreasing total $\mathrm{C}_{\mathrm{SOM}}$ content in plots with mineral $\mathrm{N}$ applied was observed.

Generally, it is obvious that silage maize monoculture cropping in a relatively short time period is significantly decreasing the $\mathrm{C}_{\mathrm{SOM}}$ content as well as its quality expressed by decreasing: (i) content of humic acids and (ii) ratio of humic/fulvic acids.

Author Contributions: Author of the main idea and the draft of the manuscript J.B. Conceptualization, analysis M.K.; methodology, basic data evaluation and analysis J.Č.; Important draft corrections and new ideas O.S. Further statistical evaluation, preparing figures and tables P.S. All authors have read and agreed to the published version of the manuscript.

Funding: This work was funded by the European Regional Development Fund-Project NutRisk Centre (No.CZ.02.1.01/0.0./0.0/16_019/0000845).

Acknowledgments: Thanks to the team of Department of Agroenvironmental Chemistry and Plant Nutrition of Czech University of Life Sciences in Prague for help and support.

Conflicts of Interest: The authors declare no conflict of interest.

\section{Abbreviations}

$\mathrm{C}_{\mathrm{SOM}} \quad$ Soil organic matter carbon compounds

$\mathrm{C}_{3} \quad$ "Old" soil organic matter

$\mathrm{C}_{4} \quad$ Carbon from maize

CHA Carbon in humic acids

$\mathrm{C}_{\mathrm{FA}} \quad$ Carbon in fulvic acids

$\mathrm{C}_{\mathrm{HU}} \quad$ Carbon in humines

$\mathrm{C}_{\mathrm{HS}} \quad$ Carbon of humic substances

$\mathrm{C}_{\mathrm{CaCl} 2}$ Carbon determined with $0.01 \mathrm{~mol} \mathrm{~L}^{-1} \mathrm{CaCl}_{2}$

$\mathrm{C}_{\mathrm{PF}} \quad$ Carbon determined with 0.1. $\mathrm{mol} \mathrm{L}^{-1} \mathrm{Na}_{4} \mathrm{P}_{2} \mathrm{O}_{7}$

$\mathrm{C}_{\mathrm{DOC}} \quad$ Easily hydrolysable $\mathrm{C}$ fraction

$\mathrm{N}_{\mathrm{t}} \quad$ total nitrogen content

DM Dry matter

FYM Farmyard manure

UAN Urea ammonium nitrate

St Straw

AS Ammonium sulfate 


\section{References}

1. Capriel, P. Trends in organic carbon and nitrogen contents in agricultural soils in Bavaria (South Germany) between 1986 and 2007. Eur. J. Soil Sci. 2013, 64, 445-454. [CrossRef]

2. Loges, R.; Bunne, I.; Reinsch, T.; Malisch, C.; Kluß, C.; Herrmann, A.; Taube, F. Forage production in rotational systems generates similar yields compared to maize monocultures but improves soil carbon stocks. Eur. J. Agron. 2018, 97, 11-19. [CrossRef]

3. Schnitzer, M. Organic matter, Principles and Processes. In Encyclopedia of Soils in the Environment, 3rd ed.; Hillel, D., Ed.; Elsevier Ltd.: Amsterdam, The Netherlands, 2005; pp. 85-93.

4. Menšík, L.; Hlisnikovský, L.; Pospíšilová, L.; Kunzová, E. The effect of application of organic manures and mineral fertilizers on the state of soil organic matter and nutrients in the long-term field experiment. J. Soil Sediment. 2018, 18, 2813-2822. [CrossRef]

5. Gregorich, E.G.; Liang, B.C.; Drury, C.F.; MacKenzie, A.F.; McGill, W.B. Elucidation of the source and turnover of water soluble and microbial biomass carbon in agricultural soils. Soil Biol. Biochem. 2000, 32, 581-587. [CrossRef]

6. Collins, H.P.; Blevins, R.L.; Gundy, L.G.; Christenson, D.R.; Dick, W.A.; Huggins, D.R.; Paul, E.A. Soil carbon dynamics in corn-based agroecosystems: Results from carbon-13 natural abundance. Soil Sci. Soc. Am. J. 1999, 63, 584-591. [CrossRef]

7. Ludwig, B.; John, B.; Ellerbrock, R.; Kaiser, M.; Flessa, H. Stabilization of maize in sandy soil in a long-term experiment. Eur. J. Soil Sci. 2003, 54, 117-126. [CrossRef]

8. Gregorich, E.G.; Ellert, B.H.; Drury, C.F.; Liang, B.C. Fertilization effects on soil organic matter turnover and corn residue C storage. Soil Sci. Soc. Am. J. 1996, 60, 472-476. [CrossRef]

9. Bettina, J.; Ludwig, B.; Flessa, H. Carbon dynamics determined by natural ${ }^{13} \mathrm{C}$ abundance in microcosm experiments with soils from long-term maize and rye monocultures. Soil Biol. Biochem. 2003, 35, 1193-1202. [CrossRef]

10. Rasse, D.P.; Mulder, J.; Moni, C.; Chenu, C. Carbon Turnover Kinetics with Depth in a French Loamy soil. Soil Sci. Soc. Am. J. 2006, 70, 2097-2105. [CrossRef]

11. Wanniarachchi, S.D.; Voroney, D.P.; Vyn, T.J.; Beyaert, R.P.; MacKenzie, A.F. Tillage effects on the dynamics of total and corn-residue derived soil organic matter in two Ontario soils. Can. J. Soil Sci. 1999, 79, 473-480. [CrossRef]

12. Flessa, H.; Ludwig, B.; Heil, B.; Merbach, W. The origin of soil organic C, dissolved organic C and respiration in long-term maize experiment in Halle, Germany, determined by ${ }^{13} \mathrm{C}$ natural abundance. J. Soil Sci. Plant. Nutr. 2000, 163, 157-163. [CrossRef]

13. Campbell, C.A.; Lafond, G.P.; Biederbeck, V.O.; Wen, G.; Schoenau, J.; Hahn, D. Seasonal trends in soil biochemical attributes: Effects of crop management on a Black Chernozem. Can. J. Soil Sci. 1999, 79, 85-97. [CrossRef]

14. Qin, R.; Stamp, P.; Richner, W. Impact of tillage on maize rooting in a Cambisol and Luvisol in Switzerland. Soil Till. Res. 2006, 85, 50-61. [CrossRef]

15. Balesdent, J.; Balabane, M. Maize root-derived soil organic carbon estimated by natural ${ }^{13} \mathrm{C}$ abundance. Soil Biol. Biochem. 1992, 24, 97-101. [CrossRef]

16. Gregorich, E.G.; Voroney, R.P.; Kachanoski, R.G. Turnover of carbon through the microbial biomass in soils with different texture. Soil Biol. Biochem. 1991, 23, 799-805. [CrossRef]

17. Ajwa, H.; Rice, C.; Sotomayor, D. Carbon and nitrogen mineralization in tallgrass prairie and agricultural soil profiles. Soil. Sci. Soc. Am. J. 1998, 62, 942-951. [CrossRef]

18. Eusterhues, K.; Rumpel, C.; Kleber, M.; Kogel-Knaber, I. Stabilisation of soil organic matter by interactions with minerals as revealed by mineral dissolution and oxidative degradation. Org. Geochem. 2003, 34, 1591-1600. [CrossRef]

19. Anonymous. Biom, Czech Biomass Association. Available online: https://czbiom.cz/blog/2019/06/06/digestat/ (accessed on 16 March 2020).

20. Anonymous. Cumulative Summaries about Soil Fund Based on Data from Cadastre of Czech Republic. Available online: https://www.cuzk.cz/Periodika-a-publikace/Statisticke-udaje/Souhrne-prehledy-pudnihofondu/Rocenka_pudniho_fondu_2020.aspx (accessed on 16 March 2020).

21. Vácha, R.; Čechmánková, J.; Duffková, R. Soil-Our Wealth [In Czech]; VÚMOP: Prague, Czech Republic, 2005; 226p. 
22. Food and Agriculture Organization of the United Nations. World Reference Base for Soil Resources 2014. International Soil Classification System for Naming and Creating Legends for Soil Maps; Food and Agriculture Organization of the United Nations: Rome, Italy, 2015; 193p. Available online: http://www.fao.org/3/i3794en/ I3794en.pdf (accessed on 1 September 2020).

23. Hauzé, V.; Tran, G.; Edouard, N.; Lebas, F. Maize Silage. Feedipedia, a Programme by INRA, CIRAD, AFZ and FAO. 2017. Available online: https://www.feedipedia.org/node/13883 (accessed on 31 August 2020).

24. Christensen, B.T. Wheat and barely straw decomposition under field conditions: Effect of soil type and plant cover on weight loss, nitrogen and potassium content. Soil Biol. Biochem. 1985, 17, 691-697. [CrossRef]

25. Wang, H.; Wang, L.; Zhang, Y.; Hu, Y.; Wu, J.; Fu, X.; Le, Y. The variability and causes of organic carbon retention ability of different agricultural straw types returned to soil. Environ. Technol. 2017, 38, 538-548. [CrossRef]

26. Guan, X.-K.; Wei, L.; Turner, C.N.; Ma, S.-C.; Yang, M.-D.; Wang, T.-C. Improved straw management practices promote in situ straw decomposition and nutrient release, and increase crop production. J. Clean Prod. 2020, 20, 119514. [CrossRef]

27. Li, D.; Li, Z.; Zhao, B.; Zhang, J. Relationship between the chemical structure of straw and composition of main microbial groups during the decomposition of wheat and maize straws as affected by soil texture. Biol. Fert. Soils. 2020, 56, 11-24. [CrossRef]

28. Schmidt, L.; Warnstorff, K.; Dörfel, H.; Leinweber, P.; Lange, H.; Merbach, W. The influence of fertilization and rotation on soil organic matter and plant yields in the long-term Eternal Rye trial in Halle (Saale), Germany. J. Plant. Nutr. Soil Sci. 2000, 163, 639-648. [CrossRef]

29. Liang, B.C.; MacKenzie, A.F. Changes in soil organic carbon and nitrogen after six years of corn production. Soil Sci. 1992, 153, 307-313. [CrossRef]

30. Balík, J.; Černý, J.; Kulhánek, M.; Sedlář, O. Soil carbon transformation in long-term field experiments with different fertilization treatments. Plant. Soil Environ. 2018, 64, 578-586. [CrossRef]

31. Ellerbrock, R.H.; Kaiser, M. Stability and composition of different soluble soil organic matter-evidence from $\delta^{13} \mathrm{C}$ and FTIR signatures. Geoderma 2005, 128, 28-37. [CrossRef]

32. USDA NRCS. Soil Survey Field and Laboratory Methods Manual; National soil survey center: Lincoln, NE, USA, 2009; 436p.

33. International Organization for Standardization. Soil Quality. Determination of Dry Bulk Density. Core Method: ISO 11272-2017; International Organization for Standardization: Geneva, Switzerland, 2017.

34. Kononova, M. M Organičeskoje Veščestvo Počvy: Jego Priroda, Svojstva i Metody Izucenija; AN SSSR: Moscow, Russia, 1963.

35. Buzek, F.; Cejkova, B.; Gersl, M.; Jackova, I.; Lnenickova, Z.; Gerslova, E. Carbon Isotope Study of soil Amendment with Maize Fermentation Digestate. IJPSS 2017, 14, 1-11. [CrossRef] 